\title{
Hepatic Cord
}

National Cancer Institute

\section{Source}

National Cancer Institute. Hepatic Cord. NCI Thesaurus. Code C34186.

A mass of cells irregularly arranged and radiating in columns away from the central vein of the hepatic lobule, many of which eventually combine to form the parenchyma of the developing liver. 